\title{
Economic cost of lameness in dairy cattle herds
}

\begin{abstract}
The long-term competitive, profitable milk-production can only be achieved by the reduction of production costs and animal diseases. These costs have become very important risk factors of herd profitability. Therefore, one of the basic aims of dairy managers today is to minimize the incidence, consequently the losses caused by herd diseases. In studies carried out in intensive dairy units showed that lameness was responsible for the third largest economic losses after mastitis and reproductive disorders, and the largest part of losses resulted from the returns foregone, that is, the diminished income due to reduced production. The aim of this study is to gain a broader knowledge about the causes of lameness, their occurrence, and how these factors have an economic impact on dairy cattle herds by influencing the production parameters. There is a wide source of literature dealing with the occurrence and the clinical and aetiological origin of the major types of lameness. The average incidence value of lameness is between $20 \%$ and $35 \%$. In order to calculate the economic cost of lameness in intensive dairy herds authors recognized the following components as the sources of losses: reduced milk receipts, decreased revenues due to longer calving interval, treatment costs, extra labour costs, cost of early culling and cost of live weight loss. The largest part of the loss due to lameness mostly came from the decreased milk receipts and the premature disposal, at the same time the drug cost could usually be blamed for the smallest cost component. The magnitude of loss resulting from lameness in dairy units is very similar in different countries, mostly varying between $€ 40-50$ per cow and $€ 100-300$ per case.
\end{abstract}

Keywords: dairy cattle, lameness, occurrence, production impact, economic cost
Volume 6 Issue 2 - 2017

\author{
László Ózsvári \\ University of Veterinary Medicine Budapest, Hungary
}

Correspondence: László Ózsvári, University of Veterinary Medicine Budapest, P.O. Box. 2. Budapest I400, Hungary, Tel +36I $4784185, \mathrm{Fax}+3614784186$

Email ozsvari.laszlo@univet.hu

Received: August 13, 2017 | Published: December 15, 2017

\section{Introduction}

The competition among dairy producers is sharp nowadays. In this challenging situation the dairies are able to survive by the continuous increase in the efficiency and thereby the profitability of their production. The level of animal health is a basic influential factor of the profitableness on dairy farms, thus, it is very helpful to reveal the herd diseases resulting in the largest economic losses. Having quantified the economic losses, cost-benefit analysis of different animal health measurements becomes possible. In surveys carried out in intensive dairy units showed that, in general, the diseases of bovine digits (lameness) causes the third largest economic losses in the dairy cattle industry after (subclinical and clinical) mastitis and reproductive disorders. It has been shown that lameness is predominant in most dairy breeds, especially in the high yielding individuals in the intensive farms. ${ }^{1}$

Lameness is not only important because it causes direct significant economic losses but it has an impact on the health. Animals suffering from lameness will show sign of discomfort. Animals will spend more time lying on the floor and are therefore more likely to develop bedsores and disorders of the udder. In addition animals with sore feet will eat less; they are more likely to develop negative energy balance (NEB) state leading to more severe secondary disease..$^{2,3}$ Lameness also raises an important issue in animal welfare. It is considered to be one of the main most painful disorders affecting cattle. The animal shows changes in behaviour and posture which is used to judge the severity of lameness. Since digital is supplied with a high number of sensory nerves, discomfort and pain will causes stress which will lead to the development of more severe disorders. Animals are more likely to get injured during culling and everyday procedures such as walking from stall/field to milk parlour. ${ }^{4}$ The aim of this study is to gain a broader understanding to the causes of lameness and how these factors have an economic impact on dairy cattle herds. In order to calculate the magnitude of economic loss we need the occurrence of lameness and its impact on production parameters.

\section{Discussion}

\section{Causes of lameness}

There are a large number of reasons why an animal can develop lameness. Lameness is not a disease but a clinical sign which may or may not be characteristic for a given disease. The foot problems causing lameness can be divided into two main categories; they can arise from either infectious or non-infectious origin. ${ }^{3}$ Infection origin can be due to bacterial, viral or fungal infection of the feet (the occurrence of the latter is rare). The main bacterial diseases causing lameness are foot rot (Fusobacterium necrophorum) and septic arthritis. The viral diseases that result in the lameness are those which have an impact on the hoofs or joint capsules in some way. The infectious foot problems causing lameness are as follows: ${ }^{3,5,6}$

\section{a. Interdigital phlegmon (Foot rot) \\ b. Interdigital dermatitis}

c. Digital dermatitis (hairy heel warts, strawberry foot rot, Mortellaro's Disease, Raspberry heel)

\section{d. Septic arthritis}

e. Deep digital infection 
Non-infectious causes can be due to housing conditions, improper nutrition, e.g. hypovitaminosis (vitamin E), or as a consequence of other metabolic diseases, e.g. ketosis or hypoglycaemia. The environmental factors and the genetic heritability can also play an important role in developing lameness., ${ }^{3,7,8}$ An English study concluded that problems with the feet accounted for $27 \%$ of all the animal hygiene related diseases. ${ }^{9}$ The incidence of lameness is higher in stall barns where there is a high relative humidity. ${ }^{10}$ Factors that might act as a precursor for lameness are free-stall housing, bedding and floor composition. Uneven flooring can be a source of trauma to the foot and improper flooring can have a highly abrasive effect on hooves especially when it is new or wet. Bitumen has one of the highest corrosive effects on the hoof. Cattle can tolerate up to 1012 hours on concrete daily. Daily access to dirt lots or pasture will minimize the wear of the hoof and provide time to heal. Pastures and roads from and to the pasture should be free of sharp gravel as they can easily damage the sole of the feet. ${ }^{11,12}$

Animals under poor hygienic condition will spend more time standing in slurry therefore they will have softer hind feet. The wet horn is softer, and softer claws are associated with more severe foot lesions. ${ }^{13}$ If the animals stand around in mud or wet bedding it will result in the softening of the hooves and erosion of the sole will be much higher. Furthermore, the wet, humid environment will favour the living environment of bacteria. Animals will spend less time laying down on wet bedding which decreases the time spent ruminating. The more time the animal spends standing the more stress will be placed on the hoof wall. Inmonths with high precipitation the prevalence of lameness has been shown to increase. The incidence of lameness was found to be higher in stall barns where there is a high relative humidity. On the other hand dry weather will causes the hoof wall to dry out and crack allowing easy access for bacteria. In cold, harsh environments frostbite can result in the necrosis of the extremities ears, tail and digits. ${ }^{3}$ Urea in urine also softens claw horn. ${ }^{14}$ Therefore, the hygienic condition and regular cleaning of stables are very important for the maintenance of healthy feet.

One of the reasons for the tendency for an increased incidence of lameness is that the genetic selection focuses mainly on milk quantity and negligees such things as teat, leg, feet conformation, quality of milk or physiology of cattle. Today genetic schemes for dairy cattle have their main focus on the quantity of milk, the fat and protein percentage of the milk, as well as, the reproductive traits, and ignoring other important traits that might prolong the animals' lifespan. There have been only a small number of studies based on the link between genetic inheritability and lameness. ${ }^{15}$

The non-infectious foot problems resulting in lameness can be seen beneath: $: 3,5,6$
i. Laminitis
ii. Horizontal fissure in hoof
iii. Degenerative joint disease
iv. Sole ulcer/sole haemorrhage
v. Toe abscess/ulcer

vi. Other causes (e.g. bone fracture, nerve damage, spinal injury; dislocation of joints, articular erosion, white muscle disease, chronic selenium toxicosis)

\section{Occurrence}

Lameness is modification of animals' gait. Accurate assessment of the incidence of lameness is difficult because farmers usually do not recognise the early signs. It takes careful observation and practice. Judgement of lameness should be carried out by trained professionals who are able to observe the early indications of lameness. Lameness scoring should be carried out on a regular basis, at least every 6 months. ${ }^{16}$ Today there are a number of lameness scoring (LS) systems present $(0-3,1-5,1-10)$ for evaluating an individual such as rear view hind limb posture, the posture and stride and based on back posture. The simplest being the $0-3$ scoring system in which: 0 is given if no lameness is present, 1) if the animal presents minor lameness, 2) in case of progressive lameness and 3) is given for severe lameness. ${ }^{5,6}$ Sprecher et al. ${ }^{17}$ created a 5-point locomotion score system, which places the emphasis on the back posture of the animals. The occurrence of bovine digital disease is common all over the world. In 39 studies published between 1972 and 1995 the incidence of lameness in dairy herds was $1.8 \%$ to $30 \%$, the average annual incidence was $7 \% .{ }^{18}$ Most of the cases are diagnosed in large-scale intensive production dairy units. Surveys carried out in several countries are summarized in Table $1 .^{1,2,9,19-30}$ In Great-Britain the incidence of lameness is shown to be between $2-20 \%$, the most significant value is between $25 \%$ and $55 \%$, but since the 1960 's the frequency has been on the increase.

Table I The incidence of lameness in different countries

\begin{tabular}{|c|c|c|c|}
\hline Country & Year & $\begin{array}{l}\text { Cases/1 } 00 \\
\text { heads }\end{array}$ & Reference \\
\hline \multirow{7}{*}{ Great-Britai } & 1958 & 4 & Leech et al..$^{19}$ \\
\hline & 1983 & 25 & Whitaker et al. ${ }^{20}$ \\
\hline & 1989 & 31 & Collick et al. ${ }^{21}$ \\
\hline & & & \\
\hline & 1993 & 36 & Esslemont \& Spincer ${ }^{22}$ \\
\hline & 1996 & 55 & Clarkson et al. ${ }^{23}$ \\
\hline & 1996 & 17 & Esslemont \& Kossaibati ${ }^{9}$ \\
\hline Holland & 1997 & 21 & Dijkhuizen \& Morris² \\
\hline \multirow{2}{*}{ USA } & 1993 & 15 & Wells et al. ${ }^{25}$ \\
\hline & 2010 & 30 & Shearer ${ }^{26}$ \\
\hline Denmark & 1995 & 7 & Alban ${ }^{27}$ \\
\hline Germanyl & 2008 & 19 & Dippel et al. ${ }^{28}$ \\
\hline \multirow[t]{2}{*}{ Austria I } & 2009 & 31 & Dippel et al. ${ }^{28}$ \\
\hline & 2001 & 25 & Györkös ${ }^{29}$ \\
\hline \multirow[t]{2}{*}{ Hungary } & 2002 & 40 & Ózsvári' \\
\hline & 2005 & 19 & Ózsvári et al. ${ }^{30}$ \\
\hline
\end{tabular}

On organic farms

In the United Kingdom in 1996 the prevalence of lameness was $20 \%,{ }^{23}$ in $200322 \%,{ }^{31}$ in $200525 \%,{ }^{32}$ in 2010 it was $37 \% .{ }^{33}$ When the prevalence rate of lameness was reported by the vets in the UK 
in 2005 it was between $4-6 \%$ only. But the actual prevalence of lameness was much higher, about $25 \%$ according to the locomotion score (LS) system and the prevalence of the lameness between farms changed between $3-100 \%$ (a very low number of individuals affected or even the whole herd can be affected simultaneously). ${ }^{32}$ Within the United States the average prevalence of lameness was about $13.2 \%$ in Wisconsin, ${ }^{34} 30 \%$ in Iowa ${ }^{26}$ and $54.8 \%$ in North East US dairy herds. ${ }^{3.5}$ In other countries all over the world (e.g. Romania, Canada, Finland, New-Zealand and China,) the prevalence of lameness varied between $15.2 \%$ and $31 \%{ }^{36-40}$ In Hungary in the large-scale dairy units the average prevalence of lameness is more than $10 \%$, but is not rare that the prevalence of dermatitis digitalis is over $50 \%{ }^{29,41}$ The prevalence on different farms can have a wide range varying from 2 to $54 \% .{ }^{23}$ This suggests that different factors such as housing, nutrition and management play an important role in the occurrence of lameness. It has been reported that $99 \%$ of lameness involves the feet instead of the whole $\operatorname{leg}^{23}$ and that $92 \%$ of these cases were present on the hind feet. ${ }^{42}$ Murray et al. ${ }^{42}$ found that $14 \%$ of the lesions were on the inner claw, $20 \%$ in the skin of the foot, and $65 \%$ of lesions were in the outer claw. According to Endres \& Salfer ${ }^{43}$ on a farm sole, ulcers occurred with the highest percentage (18.4\%), followed by white line disease (10.4\%) and sole haemorrhage (6.4\%).

\section{Causes of economic losses}

The economic losses due to lameness in dairy cattle industry are the result of clinical manifestation of the diseases and it leads to production losses rather than to the cost of treatment of the affected animals. In developed areas lameness can be blamed for the third largest economic loss after clinical/subclinical mastitis and reproductive disorders. ${ }^{1}$ In developing countries the major factors affecting the economy of the dairy industry are infectious diseases and malnutrition followed by lameness. ${ }^{44}$ The economic losses owing to diseases of the bovine digit can be divided into subgroups: direct and indirect costs. ${ }^{45,46}$

Indirect costs include: 45,46

a. Reproductive disorders

b. Loss of milk yields due to pain

Direct cost includes..$^{45,46}$

a. Veterinary cost for treatment (including cost of milk discarded due to antibiotic therapy)

b. Extra labour cost (by the owner, employees)

c. Cost of early culling

d. Based on the literature the major sources of herd-level economic losses due to lameness are shown in Figure 1. ${ }^{47}$

Reduced milk receipts: The reduced milk receipts are comprised of two components: firstly the decreased milk yield, and secondly the discarded milk due to antibiotic treatment. The largest economic losses came from the significant reduction in milk yields. Dairy cows that do not develop lameness due to housing problems are likely to become lame just before the early lactation period. ${ }^{48}$

There have been a numerous studies indicating how lameness results in the decrease of the milk yield. Lame cows do not go to pasture, feed less from the main bunk and spend most of their time lying down. If the cows are not able to get the proper daily nutrient intake, their body condition score will decrease and they cannot maintain their milk production. Owing to the pain resulting from lameness the animal will be stressed therefore resulting in a lower production of milk and a worse let-down of milk during milking. Due to the stress not only the quantity of milk is decreased but also the quality of milk lowers. ${ }^{45}$

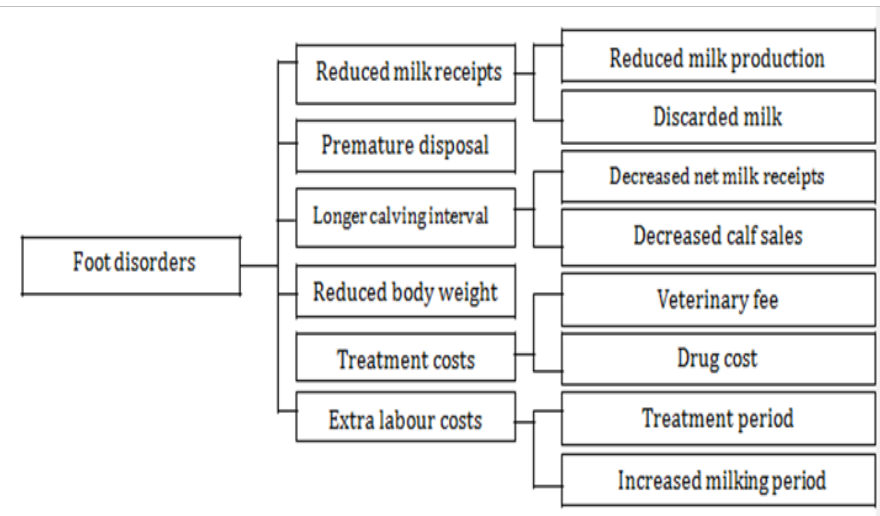

Figure I Losses due to lameness on herd level.

In assessing the quantity of milk loss, different calculation approaches can be used. Green et al. ${ }^{49}$ and Amory et al. ${ }^{50}$ calculated the losses as the margin between the actual milk production of the animals with lameness and that which is supposed to be without lameness. Warnick et al. ${ }^{45}$ and Hernandez et al. ${ }^{51}$ estimated the milk loss by comparing the affected animals before and after treatment to individuals that were not affected in the herd. Green et al. ${ }^{49}$ showed that cows showing clinical lameness had a decreased milk yield by 160 to $550 \mathrm{~kg}$ per lactation and the animals which were not affected by lameness in their life had a $1.12 \mathrm{~kg}$ higher milk yield per milking than the ones suffered from 104 to $295 \mathrm{~kg}$. Warnick et al. ${ }^{45}$ reported a reduced milk production from 295104 to $104295 \mathrm{~kg}$ in cows that developed clinical lameness after day 100 of milking. In Hungary in the large-scale dairies the average decrease owing to lameness for a lactation was $579 \mathrm{~kg}$ $(7.8 \%)$ and the average quantity of discarded milk due to antibiotic treatment was $189 \mathrm{~kg}\left(2.6 \%\right.$ of the lactation).$^{30}$ The higher yielding cows are more likely to develop lameness and suffer a greater loss in their milk production. ${ }^{49}$ The extent of the drop in milk production correlates with the type of the foot lesions and their severity. A study in Florida showed that foot rot during the early post partum period would result in $10 \%$ decrease in the milk production compared to that of healthy individuals in the herd. ${ }^{5}$ In the US on a farm with a population of 531 cows, the interdigital phlegmon resulted in greatest reduction in milk loss in comparison to other foot lesions. ${ }^{51}$ The most common feet disorder causing reduction in milk yield was sole ulcer (SU) followed by interdigital phlegmon, at the same time the digital dermatitis had minimal detrimental impact on milk yield. ${ }^{45}$ High yielding cows are more likely to develop sole ulcers or white line disease, but the development of digital dermatitis did not show any correlation with the milk yield of the animals. ${ }^{50}$ Animals with sole ulcer and white line disease had a decrease in milk yield per lactation of $574 \mathrm{~kg}$ vs. $369 \mathrm{~kg}$, whereas digital dermatitis or other foot lesions caused minimal decrease in milk yield therefore their contribution to economic losses is much smaller. ${ }^{50}$

Extended calving interval: Lameness has an adverse effect on the reproductive performance of the animals, because they have movement difficulties with movement. Therefore, their body condition worsens; the detection of oestrus is reduced or absent, and the cows need more services, thus the calving interval and the number of emp- 
tydays increase that results in higher production costs. ${ }^{1,2,24,52}$ Having known the average calving interval of the healthy animals and that of cows suffering from distal limb disease makes it possible to recognize the alteration in its length. By using the method applied in previous studies, ${ }^{2,30,53-54}$ the financial loss of longer calving interval (cost of opendays) can be calculated. The lame cows' average calving interval compared with that of healthy ones was 19days longer in Great-Britain $^{22}$ and 25 days in Hungary. ${ }^{30}$ Studies show that different foot diseases elongate the calving to conceptiondays. The digital dermatitis increases it by 20days, ${ }^{55}$ general lameness by 8.9 days,${ }^{56}$ sole ulcer by 40 days,${ }^{21}$ and white line disease by 30 days.${ }^{57}$ Melendez et al. ${ }^{58}$ reported that cows having lameness 30days after postpartum had a lower conception rate ( $17.5 \%$ vs. $42.6 \%)$, lower overall pregnancy rates $(85.0 \%$ vs. $92.6 \%)$ and higher incidence of cystic ovarian diseases $(25.0 \%$ vs. $11.1 \%)$. The numbers indicate a great decrease in number of calves born per year and also indicate a reason for involuntary culling of the animals.

Treatment costs: In practice, usually the more severely lame cows are treated, and their treatment can comprise of different approaches. In Hungary $78,5 \%$, in Great-Britain $60 \%$ of animals suffering from lameness receive treatment from a veterinarian. ${ }^{2,30}$ The veterinary costs include the vet's fee and the cost of drugs. ${ }^{1,2}$ The vet's fee is greatly influenced by the area of the country the farms is located. It also varies on the practice because some vets work with a fixed yearly call out fee. The cost of pharmacological treatment depends on the type and severity of the foot lesions. In most cases lame cows require multiple treatments and usually have to be treated twice a day, depending on the severity and duration of the disease. ${ }^{59}$ The hoof-trimming of the animals in many countries are always carried out when it is clinically indicated. In this case the curative hoof trimming has to be included in the cost calculation. (Nevertheless, in many other countries at least once a year the whole herd is examined and undergoes hoof-trimming as a prevention tool for lameness. In this case its cost is not included in the loss assessment, since this is not part of the therapeutic treatment.) The herd prevalence of curative hoof trimming in Hungary was $9.3 \%$ on average (but $48 \%$ of lame cows were trimmed) and its average cost was $€ 4.90 /$ cow. $^{30}$

If the lame cows receive parenteral, intramuscular antibiotic medication, there will be residues in the milk, therefore, the drugs withdrawal period have to be noted, resulting in certain amount of discarded milk that causes reduction in the milk receipts. In Hungary the average length of the withdrawal period was 11days after the onset of antibiotic medication of a lactating cow with foot disorder. ${ }^{30}$ In severe cases surgical interventions might be necessary under local or general anesthesia. The amputation of the digit provides rapid pain relief and it is relatively inexpensive. The animals will return to normal lactation within a few weeks, however approximately $30 \%$ will be culled within the first 7 month after amputation, and over $80 \%$ of total animals with amputation will be culled within 12 months due to decrease quality of life. ${ }^{60}$

Extra labour costs: As in case of other diseases, but particularly with lameness, the extra labour cost of the herdsmen treating lame cows has also to be taken into account. ${ }^{61,62}$ This cost arises in two different ways: (1) the extra time necessary for the farmers to treat the animals, and (2) the animals that are affected by some sort of foot disorder walk slower, therefore, the duration of herding the animals from the field/barn up to the milking parlour will increase, that is, the milking time is lengthened. When calculating the extra labour cost we have to take into consideration who is actually treating the animals. In the case that employees are needed to be recruited or existing workers have to work overtime, the costs are calculated here, but in the case where there is an allocated vet assigned to the farm to deal with the foot problems, the extra cost arises as veterinary fee. In England the distribution of animals treated by farmers vs. vets was $75 \%$ to $25 \%$ in $1983,{ }^{20}$ later $51 \%$ of animals were treated by the farmer, $37 \%$ by vets, $9 \%$ by professional hoof trimmers and $3 \%$ of the treatments were carried out by students or other personnel. ${ }^{42}$

Higher culling rate and reduced live weight: Foot problems can result in premature disposal of the animals from a dairy herd and it can be stated that the lameness is the third most common reason for early culling after mastitis and reproductive disorders. ${ }^{63,64}$ In Great-Britain the overall culling due to diseases of bovine digit was $5.6 \%$ of all disposals, and the older animals are more likely to develop lameness (3.5\% in the first lactation up to $9 \%$ in the seventh lactation). ${ }^{63}$ In California (USA), culling owing to lameness was responsible for $28.9 \%$ of all the premature disposals. ${ }^{65}$ In Hungary $3.73 \%$ of all the cows were averagely culled because of lameness, which was $10.4 \%$ of all culled animals and $19.4 \%$ of animals with disorders of bovine digit. $^{30}$

The cost of premature culling can easily be calculated as the margin of the slaughter value of the culled cows and the cost of replacement heifers. The slaughter value of the culled cows will be greatly reduced due to feet disorders because the lame cows usually have a significant weight loss, which has to be taken into consideration in the loss calculations. A British study indicates that animals sent for slaughter due to lameness receive about half the value of a healthy one, because the lame animals cannot graze or eat as much due to discomfort and that is why they have a lower body condition score than that of the healthy individuals. ${ }^{31}$ In Hungary the live weight of lame cows decreased by $6.6 \%(41.7 \mathrm{~kg})$ compared to that of healthy ones and their slaughter weight was $31.2 \mathrm{~kg}$ less $(5.4 \%)$ than that of cows culled for other reasons. ${ }^{30}$

\section{The cost of lameness}

Surveys on financial losses caused by lameness in intensive dairy herds have been carried out in several countries so far and their findings are summarized in Table $2.1,2,20,30,46,62,66-71$ The losses owing to lameness in Great-Britain were accounted for $27 \%$ of the total animal health cost in a dairy herd (vs. $38 \%$ for the mastitis) ${ }^{61}$ and in the Netherlands they were accounted for $4-5 \%$ of total income on a dairy farm. ${ }^{56}$ In England the average annual loss per average cow due the lameness was amounted to be $£ 34.61$, out of which $£ 15.47$ stemming from the reduced milk yield, $£ 5.20$ from the cost of premature disposal, and $£ 13.95$ from treatment costs. ${ }^{68}$ In Holland the annual cost of lameness was estimated to be $€ 27$ per average cow, which is shown in Table $3{ }^{2}$ In Hungary the average annual cost of lameness per cow was $€ 61.60$ EUR in 2005 . The majority of this loss (45\%) came from the decreased milk receipts, followed by the cost of early culling (39.4\%), at the same time the treatment cost could be blamed for $2 \%$ of total cost. A lameness case caused $€ 320.20$ loss on average in 2005 (Table 4). ${ }^{30}$ Based on the study findings it can be concluded that the largest part of the financial loss was resulted from the returns foregone, that is, the diminished income due to reduced production. 
Table 2 The financial losses caused by lameness and their sources in different countries

\begin{tabular}{|c|c|c|c|c|c|c|}
\hline Country & Year & in country & $\begin{array}{l}\text { Loss per } \\
\text { cow }\end{array}$ & per case & Sources of Losses & Reference \\
\hline \multirow{5}{*}{ Great-Britain } & 1978 & ŁI 5.5 mill. & & & & Baggott \& Rusell ${ }^{66}$ \\
\hline & 1986 & $£ 66$ mill. & & & $\begin{array}{l}\text { reduced milk yield, reduced live weight, } \\
\text { treatment cost longer calving interval }\end{array}$ & Wesley $^{67}$ \\
\hline & 1990 & $£ 89$ mill. & $£ 45$ & $£ 227-297$ & & Esslemont ${ }^{62}$ \\
\hline & 1998 & $£ 79.8$ mill. & $£ 34.61$ & & $\begin{array}{l}\text { reduced milk yield, early culling, treatment } \\
\text { cost }\end{array}$ & The Univ. of Reading ${ }^{68}$ \\
\hline & 1999 & $£ 90$ mill. & & & & Bennett et al. ${ }^{69}$ \\
\hline \multirow{2}{*}{$\begin{array}{l}\text { The } \\
\text { Netherlands }\end{array}$} & 1997 & & $\$ 27$ & $\$ 127$ & $\begin{array}{l}\text { reduced milk receipts, early culling, reduced } \\
\text { live weight, treatment cost, longer calving } \\
\text { interval, extra labour cost }\end{array}$ & Dijkhuizen \& Morris ${ }^{2}$ \\
\hline & 2010 & & & $\$ 95$ & $\begin{array}{l}\text { reduced milk receipts, early culling, treatment cost, } \\
\text { longer calving interval, extra labour cost }\end{array}$ & Bruijnis et al. ${ }^{46}$ \\
\hline \multirow[t]{2}{*}{ EU-I5 } & 2002 & $€>\mid$ billion & & & & Báder \& Györkös ${ }^{70}$ \\
\hline & 2001 & & & 54.50 & & Lehoczky $^{71}$ \\
\hline \multirow[t]{2}{*}{ Hungary } & 2002 & & 41.80 & 104.10 & $\begin{array}{l}\text { reduced milk receipts, early culling, treatment } \\
\text { cost, longer calving interval }\end{array}$ & Ózsvári' \\
\hline & 2005 & & 61.60 & 320.10 & $\begin{array}{l}\text { reduced milk receipts, early culling, treatment cost, } \\
\text { longer calving interval, reduced live weight }\end{array}$ & Ózsvári et al. ${ }^{30}$ \\
\hline
\end{tabular}

Table 3 Estimated annual losses due to lameness in Holland

\begin{tabular}{lll}
\hline Sources of Losses & \$ Per Case & \$ Per Cow \\
\hline Reduced milk receipts & 36 & 8 \\
Longer calving interval & 16 & 3 \\
Treatment costs & 12 & 3 \\
Extra labour costs & 17 & 4 \\
Premature disposal & 45 & 9 \\
Reduced live weight & 1 & - \\
Total & 127 & 27 \\
\hline
\end{tabular}

Table 4 Yearly losses caused by lameness in Hungary

\begin{tabular}{llll}
\hline Source of Losses & $\begin{array}{l}\text { Average } \\
\text { Cow } €\end{array}$ & Per case $€$ & Share (\%) \\
\hline Reduced milk receipts & 27.7 & 143.7 & 44.9 \\
Longer calving interval & 4.9 & 25.9 & 8.1 \\
Treatment costs & 1.2 & 6.4 & 2 \\
Premature culling & 24.3 & 126.1 & 39.4 \\
Reduced live weight & 3.5 & 17.9 & 5.6 \\
Total & 61.6 & 320.2 & 100
\end{tabular}

\section{Conclusion}

The magnitude of the loss resulting from lameness in dairy units is very similar in the different countries, though some differences can be observed due to the different economic circumstances and exchange rates. Recent study findings on financial losses caused by herd diseases support the former results that after mastitis and reproductive disorders, foot problems are the cause behind the largest losses in dairy units. Of course we have to take into account that the causes of lameness and their economic impact could vary a lot on different farms. Therefore, we can provide a more accurate estimation of economic losses if it is based on the own database of the farm in question. The prevention of foot disorders starts with the regular checks and care of the bovine digit. This cost is far smaller than that of the treatment of the diseased animals. The chance of genetic inherited predisposition for foot disorders is not more than $15-20 \%$, thus, the health and condition of the cows' foot depends on the proper keeping, feeding and preventive care in over $80 \%$.

\section{Acknowledgements}

The Project is supported by the European Union and co-financed by the European Social Fund (grant agreement no. EFOP-3.6.1-162016-00024, project title: Innovations for intelligent specialization on the University of Veterinary Science and the Faculty of Agricultural and Food Sciences of the Széchenyi István University cooperation).

\section{Conflict of interest}

Author declares that there is no conflict of interest. 


\section{References}

1. Ózsvári L. Animal health decision-making in dairy herds (in Hungarian with English thesis). PhD. SZIE FSC, Department of Microeconomics, Gödöllő, Hungary; 2004. p. 1-145.

2. Dijkhuizen AA, Morris RS. Animal Health Economics. 1st ed. Sydney, Australia: University of Sydney; 1997. p. 1-306.

3. University of Wyoming. Lameness in cattle, horse, sheep and goat. 2013.

4. Welfare Quality ${ }^{\circledR}$ Consortium. Welfare Quality ${ }^{\circledR}$ assessment protocol for cattle. 1st ed. Lelystad, The Netherlands; 2009. p. 1-180.

5. Greenough P. Lameness in cattle. 1st ed. Oxford: Elsevier Limited; 2007. p. 1-208.

6. Kahn CM ed. The Merck Veterinary Manual. 10th ed. Merck Co, USA; 2010. p. 939-1102.

7. Amstel S, Shearer J. Manual for Treatment and Control of Lameness in Cattle. 1st ed. Ames, Iowa: Blackwell; 2006. p. 1-216.

8. Nordlund KV. Herd-based diagnosis of ruminal acidosis. Proceedings of the 12th International Symposium on Lameness in Ruminants Conference. Orlando, Florida, USA; 2002. p. 70-74.

9. Esslemont RJ, Kossaibati MA. Incidence of production diseases and other health problems in a group of dairy herds in England. Vet Rec. 1996;139(20):486-490.

10. Phillips CJC, Schofield SA. The Effect of Cubicle and Straw Yard Housing on the Behaviour, Production and Hoof Health of Dairy Cows. Animal Welfare. 1994;3(1):37-44.

11. Cook NB, Nordlund KV. The influence of the environment on dairy cow behaviour, claw health and herd lameness dynamics. Vet $J$. 2009;179(3):360-369.

12. Fjeldaas T, Sogstad A, Osteras O. Locomotion and claw disorders in Norwegian dairy cows housed in frees-stalls with slatted concrete, solid concrete, or solid rubber flooring in the alleys. J Dairy Sci. 2011;94(3):1243-1255.

13. Borderas T, Pawluczuk B, de Passillé AM, et al. Claw hardness of dairy cows: relationship to water content and claw lesions. J Dairy Sci. 2004;87(7):2085-2093.

14. Gregory N, Craggs L, Hobson N, et al. Softening of cattle hoof soles and swelling of heel horn by environmental agents. Food Chem Toxicol. 2006;44(8):1223-1227.

15. Harder B, Bennewitz J, Hinrichs D, et al. Genetic parameters for health traits and their relationship to different persistency traits in German Holstein dairy cattle. J Dairy Sci. 2006;89(8):3202-3212.

16. Csomós Z. Breeding of the Hungarian Holstein-Friesian (in Hungarian). 1st ed. Gazdakönyvtár. Budapest, Hungary; 2005. p. 182-185.

17. Sprecher DJ, Hostetler DE, Kanneene JB. A lameness scoring system that posture and gait to predict dairy cattle reproductive performance. Theriogenology. 1997;47(6):1179-1187.

18. Kelton DF, Lissemore KD, Martin RE. Recommendations for recording and calculating the incidence of selected clinical diseases of dairy cattle. J Dairy Sci. 1998;81(9):2505-2509.

19. Leech FB, Davies ME, Macrae WD, et al. Disease, Wastage and Husbandry in British Dairy Herd. Report of a National Survey in 1957-58. HMSO, London, UK; 1960. p. 1-62.

20. Whitaker DA, Kellz JM, Smith EJ. Incidence of lameness in dairy cows. Vet Rec. 1983;73(3):60-62.
21. Collick DW, Ward WR, Dobson H. Associations between types of lameness and fertility. Vet Rec. 1989;125(5):103-106.

22. Esslemont RJ, Spincer I. The Incidence and Costs of Diseases in Dairy Herds. The Dairy Information System, Department of Agriculture. Earley Gate: University of Reading, Reading, UK; 1993. p. 1-65.

23. Clarkson MJ, Downham DY, Faull WB, et al. Incidence and prevalence of lameness in dairy cattle. Vet Rec. 1966;138(23):563-567.

24. Barkema HW, Westrik JD, van Keulen KAS, et al. The effects of lameness on reproductive performance, milk production and culling in Dutch dairy farms. Prev Vet Med. 1994;20(4):249-259.

25. Wells SJ, Trent AM, Marsh WE, et al. Prevalence and severity of lameness in lactating dairy cows in a sample of Minnesota and Wisconsin herds. J Am Vet Med Assoc. 1993;202(1):78-82.

26. Shearer JK. Lameness and Welfare of Dairy Cattle. Animal Industry Report: AS 656, ASL R2520. 2010.

27. Alban L. Lameness in Danish dairy cows: frequency and possible risk factors. Preventive Veterinary Medicine. 1995;22(3):213-225.

28. Dippel S, Dolezal M, Brenninkmeyer C, et al. Risk factors for lameness in free stall-housed dairy cows across two breeds, farming systems, and countries. J Dairy Sci. 2009;92(11):5476-5486.

29. Györkös L. How can we prevent lameness in our cattle (in Hungarian). 2001.

30. Ózsvári L, Barna R, Visnyei L. Economic losses due to bovine foot diseases in large-scale Holstein-friesian dairy herds (in Hungarian). Magy Állatorv Lapja. 2007;129(1):23-28.

31. Whay HR, Main DC, Green LE, et al. Assessment of the welfare of dairy cattle using animal-based measurements: direct observations and investigation of farm records. Vet Rec. 2003;153(7):197-202.

32. Weaver AD, Jean GS, Steiner A. Bovine Surgery and Lameness. 2nd ed. Oxford: Blackwell; 2005. p. 198-258.

33. Barker ZE, Leach KA, Whay HR, et al. Assessment of lameness prevalence and associated risk factors in dairy herds in England and Wales. $J$ Dairy Sci. 2010;93(3):932-941.

34. Cook NB, Hess JP, Foy MR, et al. Management characteristics, lameness, and body injuries of dairy cattle housed in high-performance dairy herds in Wisconsin. J Dairy Sci. 2016;99(7):5879-5891.

35. Von Keyserlingk MAG, Barrientos A, et al. Benchmarking cow comfort on North American freestall dairies: Lameness, leg injuries, lying time, facility design, and management for high-producing Holstein dairy cows. J Dairy Sci. 2012;95(12):7399-7408.

36. Popescu S, Borda C, Diuga EA, et al. Dairy cows welfare quality in tie-stall housing system with or without access to exercise. Acta Vet Scan. 2013;55:43

37. Solano L, Barkema HW, Pajor EA, et al. Prevalence of lameness and associated risk factors in Canadian Holstein-Friesian cows housed in freestall barns. J Dairy Sci. 2015;98:6978-6991.

38. Sarjokari K, Kaustell KO, Hurme T, et al. Prevalence and risk factors for lameness in insulated free stall barns in Finland. Livestock Sci. s44-52.

39. Fabian J, Laven RA, Whay HR. The prevalence of lameness on New Zealand dairy farms: a comparison of farmer estimate and locomotion scoring. Vet J. 2014;201(1):31-8.

40. Chapinal N, Liang Y, Weary DM, et al. Risk factors for lameness and hock injuries in Holstein herds in China. J Dairy Sci. 2014;98:6978-6991.

41. Lehoczky J. The overview of clinical aspect of dermatitis digitalis based on German authors' publications (in Hungarian). Holstein Magazin. 2002;10(1):34-35. 
42. Murray RD, Downham DY, Clarkson MJ. Epidemiology of lameness in dairy cattle: description and analysis of foot lesions. Vet Rec. 1996;138(24):586-591.

43. Endres MI, Salfer DJ. Lameness: What is new? 2005.

44. Mohammadnia AR. Study on the Prevalence of Dairy Cattle Lameness and its Effects of Production Indices in Iran. A Locomotion Scoring Base Study. Pak J Biol Sci. 2008;11(7):1047-1050.

45. Warnick LD, Janssen D, Guard CL, et al. The effect of lameness on milk production in dairy cows. J Dairy Sci. 2001;84(9):1988-1997.

46. Bruijnis MRN, Hogeveen H, Stassen EN. Assessing economic consequences of foot disorders in dairy cattle using a dynamic stochastic simulation model. J Dairy Sci. 2010;93(6):2419-2432.

47. Ózsvári L. The economic aspects of bovine herd health (in Hungarian) In: Winfried H. Frequent bovine diseases (in Hungarian). Budapest, Hungary: Mezőgazda Kiadó - Nemzeti Agrárgazadsági Kamara; 2013. p. 211-236.

48. DEFRA. Dairy cattle lameness - Practical solutions to a persistent problem. 2008

49. Green L, Hedges V, Schukken Y, et al. The impact of clinical lameness on the milk yield of dairy cows. J Dairy Sci. 2002;85(9):2250-2256.

50. Amory JR, Barker ZE, Wright JL, et al. Associations between sole ulcer, white line disease and digital dermatitis and the milk yield of 1824 dairy cows on 30 dairy cow farms in England and Wales from February 2003-November 2004. Prev Vet Med. 2008;83(3-4):381-391.

51. Hernandez J, Shearer JK, Webb DW. Effect of lameness on milk yield in dairy cows. J Am Vet Med Assoc. 2002;220(5):640-644.

52. Garbarino EJ, Hernandez JA, Shearer JK, et al. Effect of lameness on ovarian activity in postpartum Holstein cows. J Dairy Sci. 2004;87(12):4123-4131.

53. Ózsvári L, Kerényi J. Quantification of losses due to reproductive disorders on a large-scale Holstein-Friesian dairy farm (in Hungarian). Magy Állatorv Lapja. 2004;126:523-531.

54. Ozsvári L, Tóth F, Gábor Gy, et al. The economic importance of reproductive management in dairy herds. Rev Rom Med Vet. 2007;17:37-46.

55. Rodriguez A, Hird FDJ, de Anda DW, et al. Papillomatous digita dermatitis on a commercial dairy farm in Mexicali, Mexico: Incidence and effect on reproduction and milk production. Prev Vet Med. 1997;32(3-4):275-286.
56. Enting H, Kooij D, Dijkhuizen AA, et al. Economic losses due to clinical lameness in dairy cattle. Livestock Prod Sci. 1997;49(3):259-267.

57. Lucey S, Rowlands GJ, Russell AM. The association between lameness and fertility in dairy cows. Vet Rec. 1986;118(23):628-631.

58. Melendez P, Bartolome J, Archald LF, et al. The association between lameness, ovarian cyst and fertility in lactating cows. Theriogenology. 2003;50(3-4):927-937.

59. Lehoczky J. Treatment of foot disorders of infectious origin part II (in Hungarian). 2009.

60. Pejsa TG, St. Jean G, Hoffsis GF, et al. Digital amputation in cattle: 85 cases (1971-1990). J Am Vet Med Assoc. 1993;202(6):981-984.

61. Kossaibati MA, Esslemont RJ. The costs of production diseases in dairy herds in England. Vet J. 1997;154(1):41-51.

62. Esslemont RJ. The costs of lameness in dairy herds. In: Murray RD, editor. Proceedings of 6th International Symposium on Diseases of the Ruminant Digit. 1990 July 16-20; Liverpool, UK. The British Cattle Veterinary Association and University of Liverpool; 1990. p. 237-251.

63. Esslemont RJ, Kossaibati MA. Culling in 50 dairy herds in England. Vet Rec. 1997;140(2):36-39.

64. Egger-Danner C, Cole JB, Pryce JE, et al. Invited review: overview of new traits and phenotyping strategies in dairy cattle with a focus on functional traits. Animal. 2015;9(2):191-207.

65. California Dairy Herd Improvement Association. Annual Production Summary-All herds, all cows. 2010.

66. Baggott DG, Russell AM. Lameness in cattle. $\mathrm{Br}$ Vet $J$ 1981;137(1):113-132.

67. Wesley T. The Economics of Animal Disease. Richmond: V\&O Publications; 1987. p. 1-62.

68. The University of Reading. The Economics of Lameness. 1998.

69. Bennett RM, Christiansen K, Clifton-Hadley RS. Estimating the costs associated with endemic diseases of dairy cattle. $J$ Dairy Res. 1999;66:455-459.

70. Báder E, Györkös I. Let us pay more attention to body scoring! 2002.

71. Lehoczky J. Maintenance hoof trimming (in Hungarian). Thesis. SZIE FVS, Department of Animal Hygiene, Budapest, Hungary; 2001. p. $1-34$ 